Jurnal Keperawatan Silampari

Volume 5, Nomor 1, Desember 2021

e-ISSN: 2581-1975

p-ISSN: 2597-7482

DOI: https://doi.org/10.31539/jks.v5i1.2890

\title{
PENERAPAN ATRAUMATIK CARE: AUDIOVISUAL TERHADAP PENURUNAN KECEMASAN PADA ANAK USIA PRASEKOLAH
}

\author{
Selvia Novitasari ${ }^{1}$, Weti $^{2}$, Ferasinta $^{3}$, Nopia Wati $^{4}$ \\ Universitas Muhammadiyah Bengkulu ${ }^{1,2,3,4}$ \\ selvianov@umb.ac.id ${ }^{1}$
}

\begin{abstract}
ABSTRAK
Penelitian ini bertujuan untuk mengetahui pengaruh penerapan atraumatic care dengan audiovisual untuk mengurangi atau meminimalisir kecemasan anak yang mengalami hospitalisasi saat pandemic COVID-19 di RS Harapan dan Doa Kota Bengkulu. Metode penelitian ini merupakan penelitian kuantitatif dengan desain quasi experimental. Hasil penelitian didapatkan hasil perbedaan rata-rata penurunan frekuensi kecemasan sebelum dan sesudah dilakukan intervensi adalah 2,500 dengan standar deviasi 1,761 , nilai $95 \% \mathrm{CI}$ (0,652 - 4.348), p-value didapatkan $0,018<\alpha=0,05$. Simpulan, ada pengaruh yang signifikan terhadap tingkat kecemasan anak usia prasekolah sebelum dan sesudah dilakukan intervensi audiovisual di Rumah Sakit Harapan dan Doa Kota Bengkulu.
\end{abstract}

Kata Kunci: Anak, Audiovisual, Kecemasan

\section{ABSTRACT}

This study aims to determine the effect of applying atraumatic care with audiovisuals to reduce or minimize the anxiety of hospitalized children during the COVID-19 pandemic at Harapan and Doa Hospital, Bengkulu City. This research method is quantitative research with a quasi-experimental design. The results showed that the difference in the average decrease in anxiety frequency before and after the intervention was 2,500 with a standard deviation of 1,761, the value of 95\% CI (0,652 - 4,348), p-value obtained 0.018 $<=0.05$. In conclusion, there is a significant effect on the level of anxiety of preschoolers before and after the audiovisual intervention at Harapan and Doa Hospital Bengkulu City.

Keywords: Children, Audiovisual, Anxiety

\section{PENDAHULUAN}

Anak prasekolah mempunyai kemampuan verbal dan perkembangan yang lebih baik untuk beradaptasi dalam kondisi dan situasi, tetapi penyakit dan hospitalisasi dapat menyebabkan anak stress dan mengalami kecemasan (Padila et al., 2020; Fatmawati et al., 2019). Anak usia prasekolah dapat jatuh sakit dan membutuhkan rawat inap atau hospitalisasi (Novia \& Arini, 2021).

Hospitalisasi terjadi pada saat anak sakit dan dirawat di rumah sakit serta merupakan suatu hal yang sangat krisis bagi anak. Hospitalisasi menyebabkan anak mengalami trauma dan menimbulkan gejala berupa respon regresi, cemas terhadap perpisahan, apatis, ketakutan dan gangguan tidur. Keadaan ini terjadi karena anak berusaha untuk beradaptasi dengan lingkungan asing dan baru yaitu rumah sakit, sehingga kondisi tersebut menjadi faktor stresor bagi anak maupun orangtua dan keluarga. Dampak negatif ini berkaitan 
dengan lamanya dan banyaknya jumlah pasien, berbagai prosedur invasif, serta kecemasan orang tua.

Awal tahun 2020 seluruh dunia termasuk Indonesia dihebohkan dengan merebahya virus baru yaitu corona virus atau disebut dengan COVID-19. COVID-19 merupakan jenis virus baru yang menular disebabkan oleh sindrom pernapasan akut, penularan virus ini sangat cepat oleh sebab itu WHO menetapkan bahwa COVID-19 sebagai pandemic. Kondsi yang datang tiba-tiba ini membuat masyarakat tidak siap menghadapinya baik secara fisik maupun psikis, diantara kondisi psikologi yang dialami oleh masyarakat terutama anak yang mengalami hospitalisasi adalah rasa cemas apabila tertular (Fitria, 2020).

Anak usia prasekolah memiliki motorik halus dan motorik kasar yang lebih matang dari usia toodler, pertumbuhan dan perkembangan anak sudah lebih aktif, kreatif dan imajinatif ditunjang dengan beberapa permainan edukatif. Hal ini selaras dengan hasil penelitian Harsismanto et al., (2021) yang menyatakan salah satu terapi edukatif yaitu bermain plastisin dan finger painting signifikan meningkatkan perkembangan motorik halus anak prasekolah. Dalam pertumbuhan dan perkembangannya anak membutuhkan kasih saying yang lebih dari orang tuanya dan juga lingkungannya, dengan demikian anak akan merasa nyaman dan percaya diri, seorang anak mempunyai imunitas yang lemah dan mudah terpapar penyakit, dan tidak menutupi kemungkinan anak harus dirawat dirumah sakit (Purnama et al., 2020). Beberapa hasil penelitian yang efektif dapat dilakukan saat anak hospitalisasi yaitu terapi story telling, menonton animasi kartun, terapi touch, talk dan skill play, bermain puzzle serta brain gym (Padila et al., 2019; Padila et al., 2020; Panzilion et al., 2020).

Intervensi keperawatan dapat diberikan oleh perawat melalui tindakan atraumatic care. Tindakan atraumatic care merupakan salah satu bentuk caring perawat terhadap klien (Novitasari et al., 2019). Berdasarkan hasil observasi pada anak yang mengalami hospitalisasi di RS. Harapan dan Doa yaitu dari 123 anak didapatkan 50 anak diantaranya mengalami kecemasan pada anak usia prasekolah maka anak akan menunjukkan respon marah, menangis, memberontak dan menolak untuk dilakukan tindakan apapun. Karena masih kurangnya tindakan perawat untuk mengurangi kecemasan dan ketakutan pada anak ketika akan dilakukan tindakan keperawatan selama hospitalisasi.

Karena penelitian ini dilakukan ditengah pandemic COVID-19 yang membuat orang tua ataupun anak takut untuk datang ke rumah sakit apalagi sampai di rawat maka peneliti ingin melihat bagaimana pengaruh penerapan atraumatic care dengan metode audiovisual untuk mengurangi atau meminimalisir kecemasan anak yang mengalami hospitalisasi saat pandemic COVID-19. Selain itu, penelitian ini belum pernah lakukan khususnya di tempat penelitian.

\section{METODE PENELITIAN}

Penelitian ini merupakan penelitian kuantitatif dengan desain Quasi Experimental. Peneltian ini dibagi dalam dua kelompok yaitu kelompok control (yang tidak diberikan intervensi) dan kelompok intervensi yang dilakukan penerapan atraumatik care dengan audiovisual.

Populasi dalam penelitian ini adalah seluruh anak usia prasekolah yang mengalami hospitalisasi di Rumah sakit Harapan dan Doa Kota Bengkulu. Sampel setiap kelompok memerlukan 6 orang responden dengan teknik pengumpulan data dengan menggunakan lembar observasi. Selanjutnya data dianalisis secara univariat dan bivariate. 
HASIL PENELITIAN

Analisis Univariat

Tabel. 1

Distribusi Frekuensi Jenis Kelamin dan Umur Responden

\begin{tabular}{lcc}
\hline Jenis Kelamin & F & $\%$ \\
\hline Perempuan & 2 & 33.3 \\
Laki-laki & 4 & 66.7 \\
\hline Total & 6 & 100.0 \\
\hline Umur & & \\
$>3$ Tahun & 2 & 33.3 \\
3 Tahun & 4 & 66.7 \\
\hline Total & 6 & 100.0 \\
\hline
\end{tabular}

Berdasarkan tabel 1 dari 6 responden mayoritas responden dengan jenis kelamin lakilaki sebanyak 4 orang $(66,7 \%)$. Umur responden didapatkan dari 6 orang responden mayoritas berumur 3 tahun yaitu sebanyak 4 orang $(66,7 \%)$ berumur 3 tahun.

Tabel. 2

Distribusi Frekuensi

Sebelum Intervensi

\begin{tabular}{lcc}
\hline \multicolumn{1}{c}{ Sebelum Intervensi } & $\mathrm{N}$ & $\%$ \\
\hline Cemas Ringan & 2 & 33.3 \\
Cemas Ringan-Sedang & 1 & 16.7 \\
Cemas Sedang & 1 & 16.7 \\
Cemas Berat & 2 & 33.3 \\
\hline Total & 6 & 100.0 \\
\hline
\end{tabular}

Berdasarkan tabel 2 didapatkan bahwa dari 6 responden sebelum intervensi terdapat 2 orang $(33,3 \%)$ dengan kecemasan ringan dan 2 orang $(33,3 \%)$ cemas berat.

Tabel. 3

Distribusi Frekuensi

Sesudah Intervensi

\begin{tabular}{lcc}
\hline Sesudah Intervensi & $\mathrm{N}$ & $\%$ \\
\hline Tidak Cemas & 4 & 66.7 \\
Cemas Ringan & 2 & 33.3 \\
\hline Total & 6 & 100.0 \\
\hline
\end{tabular}

Berdasarkan tabel 3 didapatkan bahwa dari 6 responden setelah intervensi terdapat 4 orang $(66,7 \%)$ tidak cemas. 
Tabel. 4

Rata-Rata Sebelum

dan Sesudah Dilakukan Intervensi

\begin{tabular}{ccccc}
\hline Variabel & Mean & N & SD & SE \\
\hline Sebelum Intervensi & 2,83 & 6 & 1,835 & 0,749 \\
Sesudah Intervensi & 0,33 & 6 & 0,516 & 0,211 \\
\hline
\end{tabular}

Berdasarkan tabel 4 menunjukkan bahwa hasil analisis juga didapatkan rata-rata nilai pre intervensi adalah 2,83 dengan standar deviasi 1,835. Sedangkan rata-rata sesudah intervensi adalah 0,33 dengan standar deviasi 0,516.

\section{Analisis Bivariat}

Tabel. 5

Perbedaan Rata-Rata Sebelum

dan Sesudah Dilakukan Intervensi

\begin{tabular}{lcccccc}
\hline \multicolumn{1}{c}{ Variabel } & Mean & SD & SE & P-Value & n & $95 \%$ CI \\
\hline $\begin{array}{l}\text { Pre Intervensi - Post } \\
\text { Intervensi }\end{array}$ & 2,500 & 1,761 & 0,719 & .018 & 6 & $\begin{array}{c}0,652- \\
4.348\end{array}$ \\
\hline
\end{tabular}

Berdasarkan tabel 5 didapatkan hasil perbedaan rata-rata penurunan frekuensi kecemasan sebelum dan sesudah dilakukan intervensi adalah 2,500 dengan standar deviasi 1,761, nilai $95 \%$ CI $(0,652$ - 4.348), p-value didapatkan $0,018<\alpha=0,05$ yang berarti ada pengaruh yang signifiakn intervensi yang dilakukan terhadap penurunan frekuensi kecemasan pada responden.

\section{PEMBAHASAN}

\section{Analisis Univariat}

Berdasarkan tabel karakteristik responden bahwa anak umur 3 tahun $(66,7 \%)$ yang banyak mengalami hospitalisasi lebih rentan terhadap penyakit. Hal ini sejalan dengan penelitian Padila et al., (2019) karena anak usia 3 tahun belum mengerti mana yang kotor dan yang bersih, kadang-kadang anak suka memungut makanan yang sudah jatuh di lantai kemudian memakannya, sehingga anak mudah terkena penyakit seperti diare, batuk dan flu, jadi dapat disimpulkan bahwa semakin muda usia anak maka akan lebih beresiko untuk mengalami hospitalisasi karena sistem kekebalan tubuh yang masih berkembang dan sangat rentan terhadap penyakit apalagi disaat pandemic COVID-19 saat ini.

Jenis kelamin anak prasekolah yang mengalami hospitalisasi pada penelitian ini yang lebih dominan adalah 4 Laki-laki ( 66,7 \%). Menurut Padila et al., (2019) menyatakan bahwa anak laki-laki banyak melakukan aktifitas, pola tidur tidak teratur dan kurang makan sehingga anak laki-laki sering mengalami sakit dibandingkan anak perempuan.

Berdasarkan tabel 2 didapatkan bahwa dari 6 responden sebelum intervensi terdapat 2 orang dengan kecemasan ringan dan cemas berat. Hasil penelitian ini sejalan dengan penelitian yang dilakukan Afiatantri \& Solikah (2020) yang menunjukkan bahwa anak yang mengalami cemas dengan kategori sedang sebanyak 5 anak (50\%) saat dilaksanakan pemasangan infus di IGD RSUD Karanganyar, sisanya kategori ringan, berat dan panik.

Kecemasan yang dialami anak prasekolah dalam masa hospitalisasi merupakan masalah yang penting, jika tidak ditangani dapat berpengaruh dalam proses tumbuh kembang. Asuhan keperawatan pada anak biasanya memerlukan tindakan invasif seperti 
injeksi atau pemasangan infus, hal ini merupakan stresor kuat yang dapat membuat anak mengalami kecemasan. Perawat biasanya akan menjelaskan prosedur ini kepada orang tua dan melakukan komunikasi terapeutik kepada anak sebelum melakukan prosedur tersebut, kondisi ini juga membuat anak menjadi panik dan biasanya melakukan perlawanan atau menolak untuk dilakukan prosedur pemasangan infus atau injeksi obat, sehingga berakibat timbulnya trauma pada anak (Mulyono et al., 2020).

Sejalan dengan penelitian yang dilakukan oleh Padila et al., (2019) mengatakan bahwa perlakuan terapi menonton kartun animasi mampu menurunkan tingkat kecemasan anak menjadi berkurang, anak akan menjadi lebih familiar dengan lingkungan rumah sakit serta anak tidak akan merasa jenuh karena waktu mereka di isi dengan kegiatan menonton kartun animasi.

\section{Analisis Bivariat}

Hasil analisis didapatkan perbedaan rata-rata penurunan tingkat kecemasan sebelum dan sesudah dilakukan intervensi pada anak usia prasekolah yang mengalami hospitalisasi didapatkan hasil perbedaan rata-rata penurunan frekuensi kecemasan sebelum dan sesudah dilakukan intervensi adalah 2,500 dengan standar deviasi 1,761, p-value didapatkan 0,018 < $\alpha=0,05$ yang berarti ada pengaruh yang signifiakn intervensi yang dilakukan terhadap penurunan frekuensi kecemasan pada responden.

Kecemasan yang dialami anak prasekolah dalam masa hospitalisasi merupakan masalah yang penting, jika tidak ditangani dapat berpengaruh dalam proses tumbuh kembang. Asuhan keperawatan pada anak biasanya memerlukan tindak invasif seperti injeksi atau pemasangan infus, hal ini merupakan stressor kuat yang dapat membuat anak cemas. Kondisi ini juga membuat anak menjadi panik dan biasanya melakukan perlawanan atau menolak untuk dilakukan prosedur pemasangan infus atau injeksi dan akan menimbulkan trauma pada anak (Mulyono et al., 2020).

Upaya dapat dilakukan agar anak yang mengalami physical distancing mengalami penurunan tingkat stress saat dilakukan hospitalisasi. Beberapa terapi tersebut seperti: terapi musik, terapi audiovisual, terapi bermain puzzle, terapi bermain mewarnai, ada juga teknik berkomunikasi secara terapeutik dan teknik mengalihkan perhatian atau distraksi. Perpaduan antara memusatkan perhatian melalui pendengaran atau audio dan melalui penglihatan atau visual disebut dengan memusatkan perhatian terhadap audiovisual, terapi tersebut bermanfaat untuk memindahkan perhatian pada anak agar kecemasan atau ketakutan menurun, rasa tidak nyaman dan tingkat stress (Fatmawati et al., 2019).

Sejalan dengan penelitian yang dilakukan Novitasari et al., (2021) didapatkan hasil uji wilcoxon signed rank test, sebelum dan sesudah diberikan intervensi maka rata-rata tingkat stress anak adalah 49,93 dan diketahui hasil uji statistik p-value adalah 0,008 maka dinyatakan bahwa hipotesis diterima, yaitu terdapat perbedaan bermakna antara sebelum dan sesudah diberikan tes, maka disimpulkan hasilnya terdapat pengaruh terapi audiovisual (film kartun) terhadap tingkat stress pada anak usia sekolah yang mengalami physical distancing.

Penelitian ini juga sejalan dengan penelitian Legi et al., (2019) yang menunjukkan ada pengaruh storytelling dan guided imagery terhadap penurunan tingkat kecemasan anak usia prasekolah yang dilakukan tindakan invasif (pemasangan infus). Storytelling dan guided imagery dapat diterapkan sebagai salah satu intervensi atraumatic care untuk menurunkan kecemasan anak usia prasekolah yang dilakukan tindakan invasif (pemasangan infus). 
Manfaat dari terapi distraksi audiovisual yaitu untuk melepaskan hormon endorphin yang berfungsi untuk mengurangi stress dan mengurangi rasa sakit. Reaksi pada anak saat menjalani Hospitalisasi yaitu rasa cemas, stress dan perubahan perilaku pada anak (Fatmawati et al., 2019). Anak yang saat ini sedang menjalani hospitalisasi sebagian besar mengalami stres. Adapula cara yang efektif untuk mengurangi stres pada anak yang mengalami hospitalisasi yaitu dengan melakukan terapi audiovisual, mendengarkan musik, bermain misalnya menonton film kartun yang disukai oleh anak tersebut selain itu orang tua harus menciptakan lingkungan yang nyaman.

Distraksi dengan audiovisual adalah salah satu pengalihan perhatian anak yang lebih efektif untuk anak usia prasekolah karena didalam intervensi menggunakan audiovisual anak-anak menggunakan alat indra mendengar dan melihat sehingga anak-anak lebih focus, distraksi audiovisual menanyangkan tokoh kartun yang lucu, lagu anak-anak yang mudah dihapal, film anak- anak yang menarik, sehingga membuat anak merasa lebih senang dan terhibur. Respon positif yang ditunjukkan oleh anak setelah diberikan intervensi dengan audiovisual anak mampu mengurangi sikap kasar terhadap tenaga medis terutama dokter atau perawat, anak tidak lagi takut ketika perawat akan melakukan tindakan keperawatan (Novitasari et al., 2019). Anak bisa bersifat tenang ketika didampingi oleh orang tua selama perawatan berlangsung. Anak yang diberikan distraksi audiovisual menunjukkan tingkat kecemasan yang berkurang dibandingkan anak yang tidak dilakukan distraksi audiovisual. Apalagi kondisi COVID-19 saat ini yang memberikan dampak yang bruk terhadap anakanak dan keluarga karena takut dan cemas (Legi et al., 2019).

\section{SIMPULAN}

Ada pengaruh yang signifikan terhadap tingkat kecemasan anak usia prasekolah sebelum dan sesudah dilakukan intervensi audiovisual di Rumah Sakit Harapan dan Doa Kota Bengkulu.

\section{SARAN}

Perawat dapat menerapkan intervensi audiovisual dalam menurunkan tingkat kecemasan pada anak usia prasekolah yang mengalami hospitalisasi dengan melibatkan orang tua dan konsep caring adalah salah satu tindakan atraumatic care. Terapi audiovisual dapat dilakukan oleh keluarga dengan penerapan Family Center Care (FCC) karena keluarga merupakan pusat dalam perawatan di rumah, dengan menerapkan audiovisual dapat memberikan rasa nyaman dan dapat mengalihkan perhatian anak. Peneliti menyarankan terhadap peneliti selanjutnya agar dapat membandingkan terapi audiovisual dengan terapi lain, memilih sampel lebih banyak dan dengan karakteristik yang berbeda.

\section{DAFTAR PUSTAKA}

Afiatantri, A. N. I., \& Solikah, S. N. (2020). Gambaran Tingkat Kecemasan saat Pemasangan Infus pada Anak di Instalasi Gawat Darurat RSUD Karanganyar. Jurnal Ilmiah Keperawatan, 9(2), 24-34. https://akperinsada.ac.id/ejurnal/index.php/insada/article/view/216

Fatmawati, L., Syaiful, Y., \& Ratnawati, D. (2019). Pengaruh Audiovisual Menonton Film Kartun terhadap Tingkat Kecemasan saat Prosedur Injeksi pada Anak Prasekolah. Journal of Health Sciences, 12(02), 15-29. DOI: 10.33086/jhs.v12i02.996

Fitria, L., \& Ifdil, I. (2020). Kecemasan Remaja pada Masa Pandemi COVID -19. Jurnal EDUCATIO: Jurnal Pendidikan Indonesia, $6(1), \quad 1$. https://doi.org/10.29210/120202592 
Harsismanto, J., Ramon, A., Putrawan, R., Padila, P., \& Andri, J. (2021). Perbandingan Efektivitas Bermain Plastisin dengan Finger Painting terhadap Perkembangan Motorik Halus Anak Prasekolah. Jurnal Kesmas Asclepius, 3(1), 25-33. https://doi.org/10.31539/jka.v3i1.2375

Legi, J. R., Sulaeman, S., \& Purwanti, N. H. (2019). Pengaruh Storytelling dan GuidedImagery terhadap Tingkat Perubahan Kecemasan Anak Usia Prasekolah yang Dilakukan Tindakan Invasif. Journal of Telenursing (JOTING), 1(1), 145-156. https://doi.org/10.31539/joting.v1i1.496

Mulyono, A., Indriyani, P., \& Ningtyas, R. (2020). Literatur Review: Pengaruh Terapi Distraksi Audiovisual pada Saat Prosedur Injeksi pada Anak Usia Prasekolah Saat Hospitalisasi. Journal of Nursing Health, 5(2), 108-115. DOI: 10.52488/jnh.v5i2.124

Novia, R., \& Arini, L. (2021). Efektivitas Terapi Bermain (Mewarnai) terhadap Penurunan Kecemasan Anak Usia Prasekolah (3-6 Tahun) yang Dirawat di Rumah Sakit Harapan Bunda Batam. Medihealth: Jurnal Ilmu Kesehatan dan Sains, 1(1), 41-52. http://jurnalmbp.org/index.php/Medihealth/article/viewFile/7/10

Novitasari, P., Ernawati, D., \& Anggoro, S. D. (2021). Pengaruh Terapi Audiovisual (Film Kartun) terhadap Tingkat Stres pada Anak Usia Sekolah yang Menjalani Physical Distancing di Rw 01 Desa Wage Kecamatan Taman Kabupaten Sidoarjo. Jurnal Ilmiah Keperawatan (Scientific Journal of Nursing), 7(1), 13-18. https://doi.org/10.33023/jikep.v7i1.673

Novitasari, S., Sulaeman, S., \& Purwati, N. H. (2019). Pengaruh Terapi Musik dan Terapi Video Game terhadap Tingkat Nyeri Anak Usia Prasekolah yang Dilakukan Pemasangan Infus. Journal of Telenursing (JOTING), 1(1), 168-177. https://doi.org/10.31539/joting.v1i1.510

Padila, P., Agusramon, A., \& Yera, Y. (2019). Terapi Story Telling dan Menonton Animasi Kartun terhadap Ansietas. Journal of Telenursing (JOTING), 1(1), 51-66. https://doi.org/10.31539/joting.v1i1.514

Padila, P., Yanti, L., Pratiwi, B., Angraini, W., \& Admaja, R. (2020). Touch, Talk dan Skill Play terhadap Penurunan Kecemasan Anak Pre-School. Jurnal Kesmas Asclepius, 2(2), 64-72. https://doi.org/10.31539/jka.v2i2.1418

Panzilion, P., Padila, P., Setyawati, A., J, H., \& Sartika, A. (2020). Stimulation of Preschool Motor Development Through Brain Gym and Puzzle. JOSING: Journal of Nursing and Health, 1(1), 10-17. https://doi.org/10.31539/josing.v1i1.1166

Purnama, B. A., Indriyani, P., \& Ningtyas, R. (2020). Pengaruh Terapi Story Telling terhadap Tingkat Kecemasan pada Anak Prasekolah dengan Hospitalisasi. Journal of Nursing and Health, 5(1), 40-51. https://doi.org/10.52488/jnh.v5i1.116 